\title{
The Street Over the River: Mediation Between Hygiene and Urbanism Through Drawing in the City of Porto
}

\section{Mariana Marques da Silva}

Tutor: Professor Marta Maria Peters Arriscado de Oliveira, Ph.D.; Professor Architect Paulo Providência, Ph.D.; Faculty of Architecture, University of Porto, Portugal E-mail address: marianadgms@gmail.com

\begin{abstract}
Urban transformations were developed in the city of Porto during the second half of the $19^{\text {th }}$ century, particularly between $1870-1890$, when the street Mouzinho da Silveira was planned and built.

Aspiring to accelerated mobility, the knowledge of military engineering in topography was applied to the planning of infrastructures such as streets, bridges, railways and tunnels in order to reconfigure entrances and circuits between the main centres of activity (downtown and uptown). Meanwhile, overpopulation and disease required medical-based knowledge about epidemiology and public health to improve inhabited spaces.

In juxtaposition, the city intersected these spheres, creating complex spatial models and new policies to control human activities. This environmental change was multifocal in European cities and solutions were devised in Lisbon, Paris and London. Considering its particular influence, it is intended to acknowledge the specific way this input was achieved and applied according to the specific conditions of Porto.
\end{abstract}

KEYWORDS: Mouzinho da Silveira; Public Health; Public Works; Public Water System; Housing; Biopolitics

\section{INTRODUCTION}

Naturally slower than progressive demands, the urban restructuring of Porto had to be pragmatic. Due to its difficult topographic conditions and predominantly me- 
dieval fabric, each improvement needed several demolitions in a context of lack of housing and living conditions. As a result, any intervention was twice as challenging, whether in choosing a strategic location or in designing a suitable solution which would answer several kinds of problems.

The intersection of different fields of knowledge made planning more complex. The urban form was not only a result of its religion, politics and economy but of its human health, when hygiene became an economy of life able to order the human bodies and their built environment.

Besides interdisciplinary knowledge, new planning models were created to order the built environment according to specific urban contexts. Among other European cities, Porto established a relation of similarities, although, it is the combination and way of adaptation to local reality, that makes it unique and a case study.

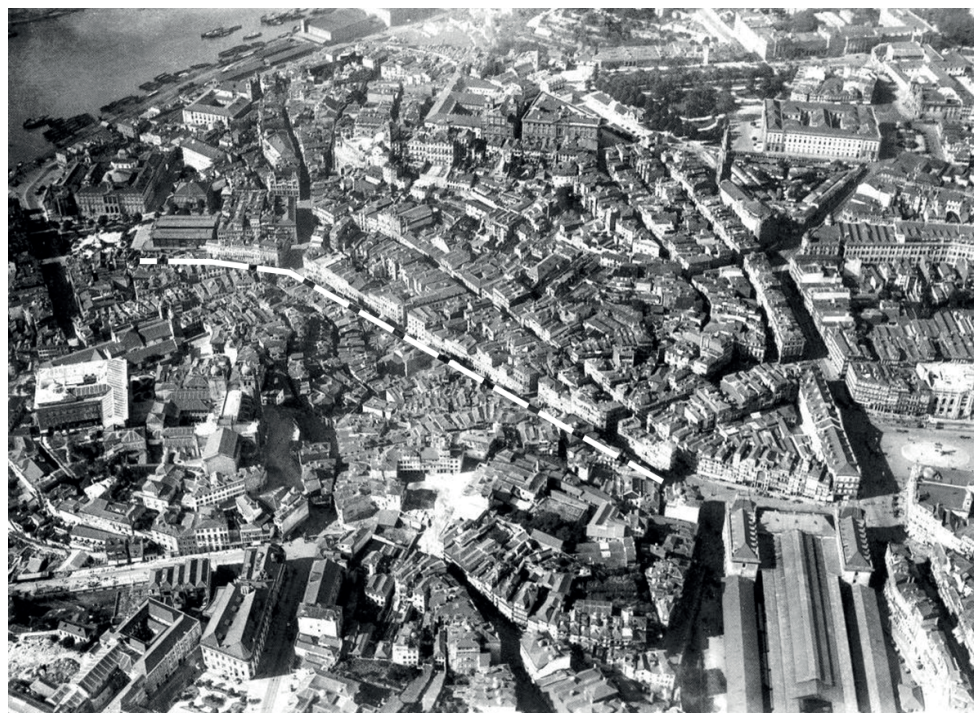

Img. 1. Aerial photograph of Porto 1939-1940 with highlighted Street Mouzinho da Silveira (Source: Foto Beleza)

The existence of a source of infection, such as Rio da Vila (Village's River), further aggravated by industrialisation, provided sufficient reason for an intervention in the city centre. Its formulation as a hypothesis was built upon an earlier project presented in 1689 , which, although it did not materialise, brought attention to the issue. However, if in the $17^{\text {th }}$ century the solution would usually be to build a "larger square" 
(Mandroux-França 1984) (Img.2) over the river as a validation of a new centrality, in the late $19^{\text {th }}$ century other premises such as acceleration and sanitation were required for the development of a city. Therefore, the plumbing of the tributary was a result of a transport need: the widening of an existing road (Img.3) into a faster street that, by crossing the medieval urban fabric, could overcome the slope and shorten the distance between the centers of activity: the municipal square, the central train station that was being planned (uptown) and the commercial, customs and port area (downtown). While there was a unanimous agreement concerning the location, its design changed from the first proposal in 1872 to its approval in 1875 and construction, having been widened to 18 meters. Such a decision was related to a second tramway track, following a legal dispute between the municipality and one of the two tram operating companies, as a sign that emphasizes the mobility demands mentioned above. Thus, the improvement meant the opening of a new street, as a symbol of a new rationality.

Such embellishment interventions, which were taking place simultaneously in other European cities, were statistically translated so that new streets were quantified in units and linear kilometres. Moreover, the opening of Rua Mouzinho da Silveira represented the largest number of expropriations and demolitions in the medieval core of the city to date.

In addition to other mobility infrastructures, the street was technically an area of expertise of engineers with military education, given the topographic characteristics of the territory. However, the sanitation of the city required new types of knowledge in the design of the spaces. Thus, the street was a structure that articulated the cell of the house and the urban system, the public and private spaces and, consequently, the spheres of public and private, collective and individual hygiene, representing what Jean-Baptiste Fonssagrives designated as "l'unité hygiénique de la ville".

The design of the street as a complex urban structure and unit comes at a time of city reconstruction, namely during the post-1755 earthquake Lisbon reconstruction, in the 1756 Baixa-Chiado design project prepared by the military engineer Eugénio dos Santos (Rossa 2004) (Img.4) and, later, in the representations of the architect Pierre Patte (Patte 1769), in 1769, who designated this type of structure as a bridge-street (Img.5).

This type of representation is the first evidence of the application of sanitary principles in the change of the city's built environment, already claimed in the Enlightenment period by the Portuguese physician Ribeiro Sanches, whose understanding of the European context had already led him to advocate for a concept of urbanism as valuing a "scientific" component in the "art" of building for health preservation. 


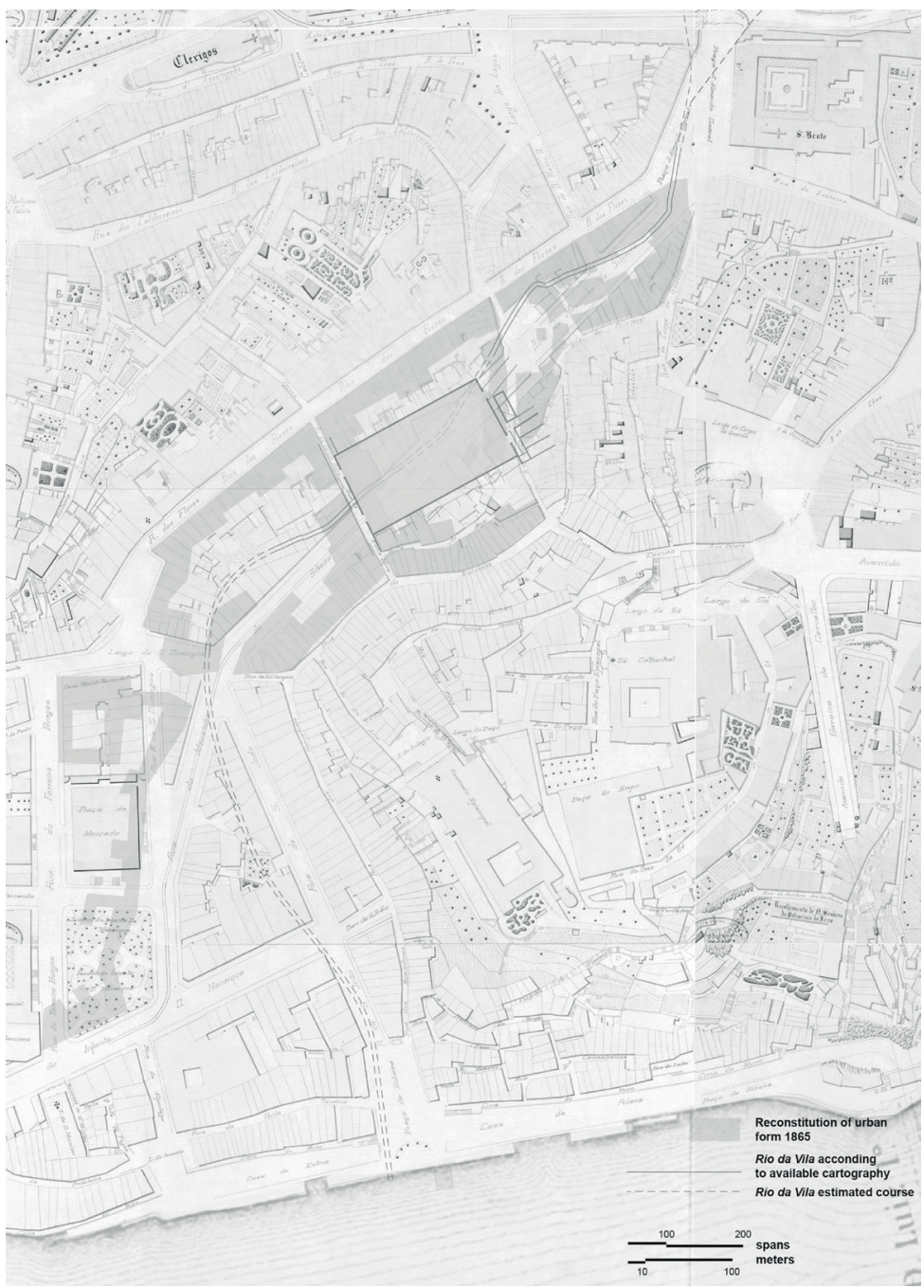

Img. 2. Location hypothesis of the New Square (Source: Mandroux-França 1984) 


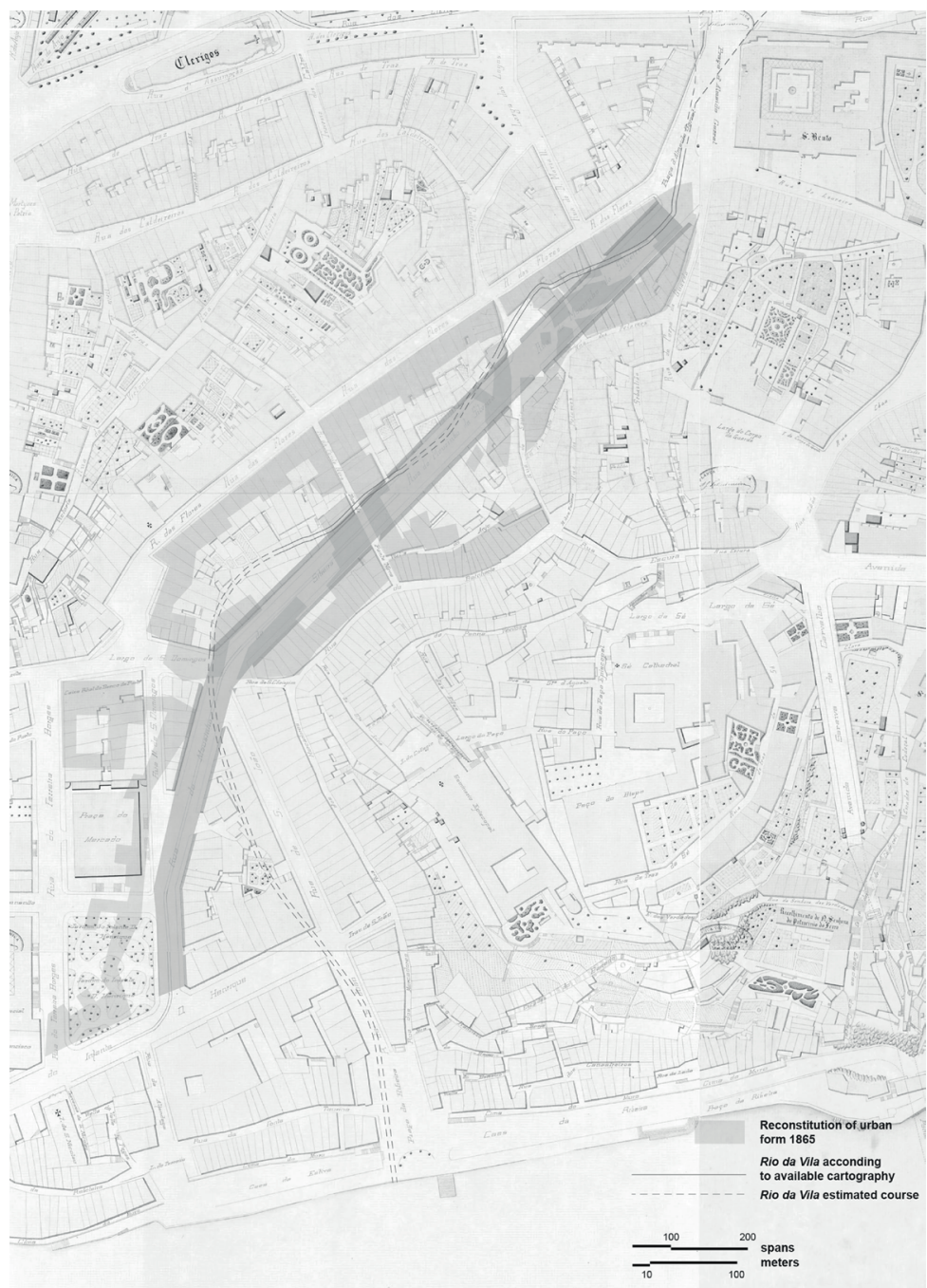

Img. 3. Project for the widening of Rua da Biquinha and the opening of Rua Mouzinho da Silveira (Source: Public Historic Archive) 
However, only in the mid- $19^{\text {th }}$ century, with the evolution of epidemiology, came a new argument for the value of hygiene as a priority. Its implementation of hygiene measures depended on their demonstration as a life and health economy presented by doctor William Farr in „Vital Statistics“ (Hughes \& Lancaster 1897) regarding the London case; by doctor Jules Rochard about France, as inspector general of the navy health service; and by doctor Ricardo Jorge about Porto (Jorge 1888).

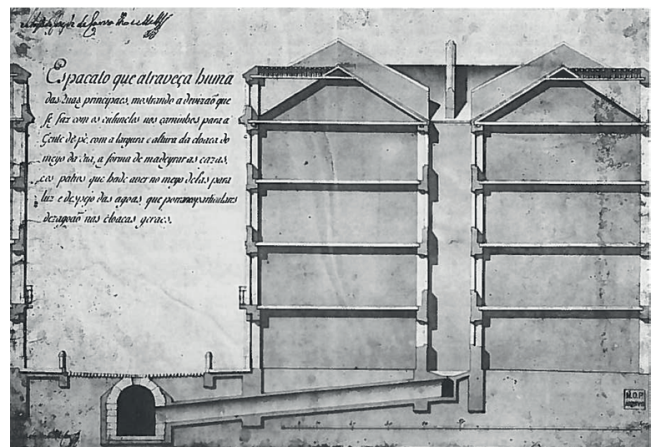

Img. 4. Baixa-Chiado's cross-section (1756-1758) Lisbon. Eugénio dos Santos (Source: Rossa 2004)

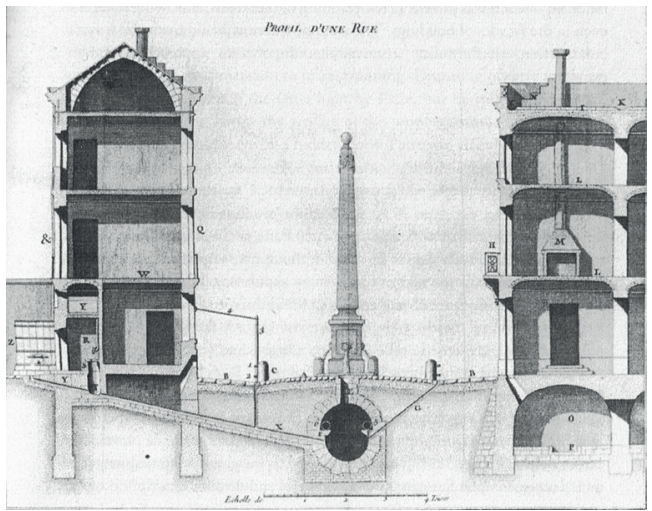

Img. 5. Street section (1769). (Source: Patte 1769)

1st:Every expense in the name of hygiene means saving money; 2nd:Excepting death, nothing is more expensive than disease; 3rd:For societies, there is nothing more ruinous than contempt for human life (Rochard 1884)

In this transitional period, it was necessary to change the type of knowledge as well 
as to move from «an economy (...) based on chrematistics, very budget and customs oriented, stronger in financial statements rather than in demography (...), without appreciation for human life, to the concept that sanitary integrity is more valuable than money» (Jorge 1888).

The epidemiological knowledge and statistical data allowed for the conversion of scientific discourse into economic language, making the reading of this reality logical and intelligible to political power. Alongside the investment in sanitation came the recognition of the value of life and the healthy body, attributed through medicine, in addition to the material value that the body already had to the law. In short, it acquired economic value and became the foundation of a new ideological structure in which hygiene becomes the economy that allows the fight against disease and death. This strategy, that Michel Foucault considers to be a social control, is at the root of his contemporary concept of biopolitics, putting in another perspective the philanthropic premises of the time:

\section{Will the ideas of today be valid tomorrow? \\ Is it possible that what seems like an indisputable truth now be later con- sidered a fanciful concept? \\ The future will tell \\ (Osório 1860)}

The future reality would confirm the underlying doubts in the words of Doctor José Frutuoso Osório to defend public health. The intensification of disciplinary interaction was reflected in the bibliographic production and in the complexity of the built urban structures.

In the city of Porto, knowledge of the French reality and local contact with English culture predominated. On the one hand, it is possible to verify the prevalence of French treaties dedicated to public and private hygiene and engineering structures. On the other hand, the knowledge and the presence of English in the dynamics of the city, was particularly manifested by the awarding of the sanitation works to the English company Hughes and Lancaster at the implementation of the separate system. This was the most suitable solution for the specific case of Porto due to costs and difficult topographic features. Unlike the French unitary system used in Paris, known as tout-à-l'egout (Img.6), it consisted in separating domestic waste water and rainwater through separate pipelines, which were also drained through the natural slope of the streets (Img.7). In this sense, while it is possible to infer from the constructed form indications of the principles of French urban medicine, conversely, the technology and devices used in the sanitation system were mainly of English design and manufacture. 


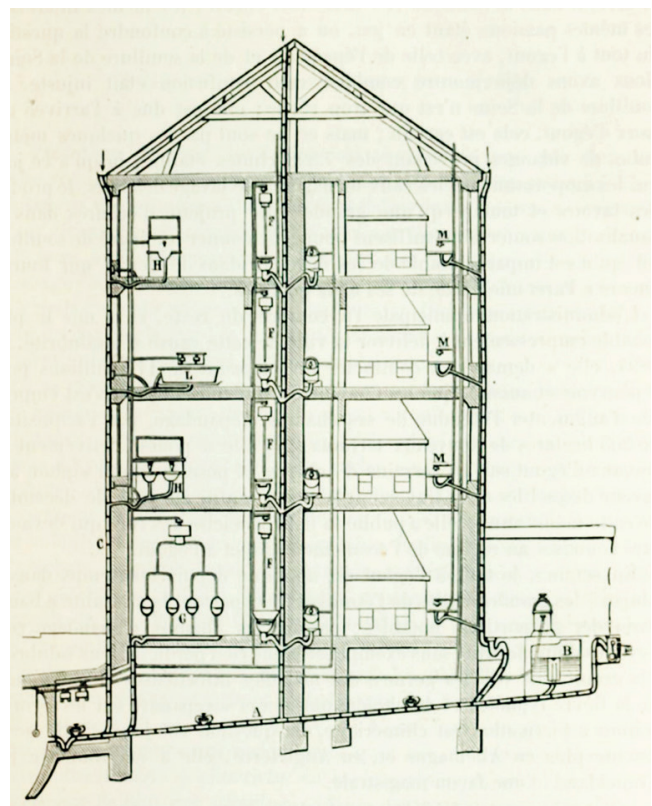

Img. 6. Section of a house in Paris with a tout-à-l'egout sewerage system (Source: Rochard 1897)

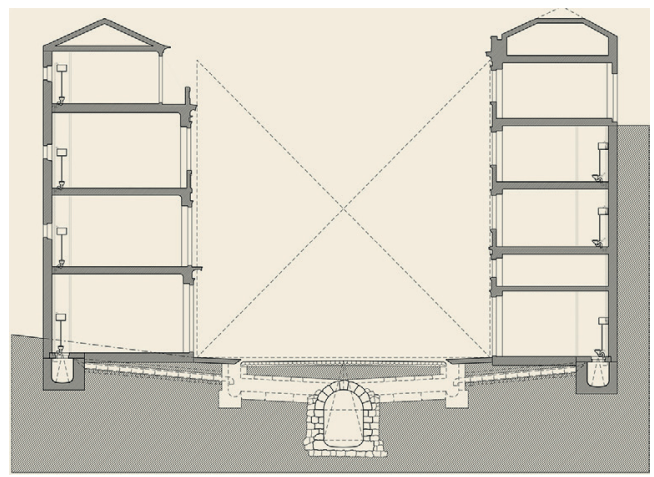

Img. 7. Rua Mouzinho da Silveira's cross-section with separated water system

In conclusion, the street became an example of a rational design that encompasses the complexity of various urban levels and layers of knowledge. They were intersected and organized according to the order of hygiene. Its application was transversal from the underground, to the road network and housing level, changing the practices and techniques applied simultaneously and respectively by military or sanitary engineers 
and architects. As an assembled structure, it is therefore impossible to isolate the sewage system from the domestic space, just as the solutions applied in Porto cannot be isolated from its topography, education and international exchange that results from the interaction between professionals and their knowledge.

\section{REFERENCES}

ANTAS, Á., 1915. Insalubridade do Porto. Porto.

FOUCAULT, M., 1979. «Naissance de la biopolitique». In Histoire des systèmes de pensée, années 1978-1979, p. 367-372. Paris.

HUGHES \& LANCASTER, 1897. Saneamento da cidade do porto pelo systema separado. Londres.

JORGE, R., 1888. Saneamento do Porto: Relatório apresentado à Comissão Municipal de Saneamento. Porto.

MANDROUX-FRANÇA, M.-Th., 1984. Quatro fases de urbanização do Porto no século XVIII. Porto.

OSÓRIO, J., 1860. A Gazeta Médica do Porto: Periódico de Medicina, Cirurgia, Pharmacia. Porto.

PATTE, P., 1769. Memoires sur les objets les plus importants de l'architecture, Paris.

ROCHARD, Jules. Congresso Internacional d'Hygiene em Haya, October 1884. In A Saúde Pública: Hebdomadário de Hygiene, Vol. 43, p. 2, Porto.

ROCHARD, J., 1897. Traité d'Hygiene Publique et Privée. Paris.

ROSSA, W., 2004. «Do plano de 1755-1758 para a Baixa-Chiado». In Monumentos 21

- Revista Semestral de Edifícios e Monumentos, Lisboa, p. 21-22

SÁ, A., 1905. O novo systema de exgottos do Porto. Porto. 